\title{
Bronchial reactivity and dietary antioxidants
}

\author{
Anne Soutar, Anthony Seaton, Katrina Brown
}

\begin{abstract}
Background - It has been postulated that dietary antioxidants may influence the expression of allergic diseases and asthma. To test this hypothesis a case-control study was performed, nested in a cross sectional study of a random sample of adults, to investigate the relationship between allergic disease and dietary antioxidants. Methods - The study was performed in rural general practices in Grampian, Scotland. A validated dietary questionnaire was used to measure food intake of cases, defined, firstly, as people with seasonal allergic-type symptoms and, secondly, those with bronchial hyperreactivity confirmed by methacholine challenge, and of controls without allergic symptoms or bronchial reactivity. Results - Cases with seasonal symptoms did not differ from controls except with respect to the presence of atopy and an increased risk of symptoms associated with the lowest intake of zinc. The lowest intakes of vitamin $C$ and manganese were associated with more than fivefold increased risks of bronchial reactivity. Decreasing intakes of magnesium were also significantly associated with an increased risk of hyperreactivity.
\end{abstract}

Conclusions - This study provides evidence that diet may have a modulatory effect on bronchial reactivity, and is consistent with the hypothesis that the observed reduction in antioxidant intake in the British diet over the last 25 years has been a factor in the increase in the prevalence of asthma over this period.

(Thorax 1997;52:166-170)

Keywords: asthma, hay fever, bronchial reactivity, diet, antioxidants.

Department of Environmental and Occupational Medicine, University Medical School, Foresterhill, Aberdeen AB9 2ZD, UK

A Soutar

A Seaton

The Rowett Research Institute, Bucksburn, Aberdeen AB2 9SB, UK

K Brown

Correspondence to: Professor A Seaton.

Received 15 May 1995 Returned to authors

4 August 1995

Revised version received

31 July 1996

Accepted for publication

16 September 1996
The well known increase in the prevalence of asthma and other allergic diseases in westernised countries remains unexplained. ${ }^{1-6} \mathrm{We}$ have argued that such a large increase in asthma, eczema, and hay fever is unlikely to be explained by changes in the air we breathe, either in terms of its allergen content or in the amount of pollutants such as cigarette smoke or those derived from traffic and industrial sources. Rather, we have proposed that the populations of economically advanced countries have eaten a diet which has included progressively less fresh fruit and vegetables and that this diet has increased the susceptibility of the population as a whole to potentially harmful inhaled substances by reducing the antioxidant defences of the lung against the effects of inhaled irritants and allergens. ${ }^{7}$ It is likely that, if this hypothesis were true, the diets that would influence the prevalence of allergic disease in children most critically would be those of the mother in pregnancy and during lactation and of the child in the first year or two of life. However, since asthma may start at any age an effect may be demonstrable at any time, and we have taken the opportunity to investigate diet in adults, with and without increased bronchial reactivity, derived from a random sample of a rural population.

\section{Methods}

SELECTION OF INDIVIDUALS

The original cross sectional study population consisted of 2000 individuals, an approximately one in 10 random sample of all adults registered with the general practitioners of three villages in rural Grampian, Scotland. ${ }^{8}$ All had completed questionnaires on the presence or absence of a range of seasonal symptoms including those classically associated with allergy. Cases were first defined as those who had responded positively to questions about recurrent eye, nasal, or respiratory symptoms any time between April and August ${ }^{8}$ and controls were those with no such seasonal symptoms. The cases selected from the original population for the present study were all those from one of these villages who had recorded seasonal symptoms on the questionnaire, together with age and sex matched controls without symptoms from the same village. They were contacted by telephone and those who agreed to participate were sent a detailed dietary questionnaire through the post with instructions on how to complete it. Of 78 cases and 68 controls approached, 52 and 38, respectively, took part. The main reasons for not participating did not differ between cases and controls, 10 and 13, respectively, having moved, six and four being ill or having died, and 10 and 13 being unwilling or unable to attend.

Subjects taking bronchodilators or antihistamines were asked to stop them six or 48 hours, respectively, before attending for further tests. They were then seen and the completed questionnaire was checked. A second questionnaire to confirm the presence or absence of symptoms was administered and a clinical history taken. Skin prick tests and a methacholine challenge test were then carried out. A second group of cases was defined as those who showed a fall of $20 \%$ or greater in forced expiratory volume in one second $\left(\mathrm{FEV}_{1}\right)$ in response to $12.25 \mu \mathrm{mol}$ or less of methacholine, controls being those who showed no such change at this level.

All tests were carried out during the winter and care was taken to ensure that no subject had suffered a viral infection in the six weeks prior to the test. 
Table 1 Characteristics of those with (cases) and without (controls) a history of seasonal symptoms

\begin{tabular}{|c|c|c|c|}
\hline & $\begin{array}{l}\text { Cases } \\
(n=51)\end{array}$ & $\begin{array}{c}\text { Controls } \\
(n=38)\end{array}$ & $p$ value \\
\hline $\mathrm{M}: \mathrm{F}$ & $16: 35$ & $14: 24$ & 0.589 \\
\hline Mean (SD) age & $36.6(11.09)$ & $38.3(10.42)$ & 0.451 \\
\hline \multicolumn{4}{|l|}{ Smoking habits: } \\
\hline Current smokers & 12 & 10 & \\
\hline Ex-smokers & 7 & 9 & 0.389 \\
\hline Never smokers & 32 & 19 & \\
\hline Atopy & 39 & 2 & $<0.001$ \\
\hline Mean (SD) $\mathrm{FEV}_{1}$ (\% predicted) & $115.1(16.08)$ & $111.7(14.01)$ & 0.296 \\
\hline Mean (SD) FVC (\% predicted) & $113.6(13.97)$ & $108.9(14.74)$ & 0.131 \\
\hline Mean (SD) $\mathrm{PD}_{20}(\mu \mathrm{mol})$ & $7.8(2.59)$ & $11.7(1.95)$ & 0.038 \\
\hline \multicolumn{4}{|l|}{ Previously diagnosed: } \\
\hline Asthma & 7 & 1 & 0.070 \\
\hline Hay fever & 40 & 0 & $<0.001$ \\
\hline Eczema & 9 & 2 & 0.079 \\
\hline Allergy & 13 & 3 & 0.032 \\
\hline
\end{tabular}

$\mathrm{FEV}_{1}=$ forced expiratory volume in one second; $\mathrm{FVC}=$ forced vital capacity; $\mathrm{PD}_{20}=$ dose of methacholine provoking a $20 \%$ fall in $\mathrm{FEV}_{1}$.

Table 2 Daily antioxidant and total energy intake for those with symptoms (cases) and those without (controls)

\begin{tabular}{lccccc}
\hline & Cases & & & \multicolumn{2}{l}{ Controls } \\
\cline { 2 - 3 } \cline { 5 - 6 } & $\begin{array}{l}\text { Geometric } \\
\text { mean }\end{array}$ & $\begin{array}{l}\text { Confidence } \\
\text { interval }\end{array}$ & & $\begin{array}{l}\text { Geometric } \\
\text { mean }\end{array}$ & $\begin{array}{l}\text { Confidence } \\
\text { interval }\end{array}$ \\
\hline Retinol $(\mu \mathrm{g})$ & 756 & 637 to 898 & & 784 & 619 to 992 \\
$\beta$-carotene $(\mu \mathrm{g})$ & 1951 & 1630 to 2335 & & 2107 & 1842 to 2409 \\
Vitamin C $(\mathrm{mg})$ & 97.3 & 82.2 to 115.2 & & 104.0 & 87.0 to 124.3 \\
Vitamin E $(\mathrm{mg})$ & 6.99 & 6.07 to 8.06 & & 7.92 & 6.85 to 9.15 \\
Magnesium $(\mathrm{mg})$ & 294 & 267 to 322 & & 331 & 302 to 362 \\
Zinc $(\mathrm{mg})$ & 9.32 & 8.56 to 10.14 & & 10.92 & 9.80 to 12.18 \\
Manganese $(\mathrm{mg})$ & 2.93 & 2.59 to 3.32 & & 3.33 & 2.85 to 3.90 \\
Selenium $(\mu \mathrm{g})$ & 62 & 55 to 70 & & 73 & 63 to 85 \\
Energy intake $(\mathrm{kcal})$ & 1947 & 1767 to 2145 & 2169 & 1952 to 2410 \\
\hline
\end{tabular}

The study protocol was approved by the local ethical committee and all subjects gave fully informed consent to their participation.

DIETARY QUESTIONNAIRE

The questionnaire, which has been validated previously against weighed intake and in epidemiological studies of heart disease, ${ }^{910}$ established present and past dietary intake. Mean daily intake is estimated from daily frequency of food consumption over a seven day period. Information on any vitamin, mineral, and food supplements taken was recorded - that is, type, brand, strength, and frequency of consumption. This was not dealt with by the computer program and such information had to be input separately and the intakes altered accordingly.

ALLERGY TESTS

Skin prick tests were performed to 10 common allergens: house dust mite (Dermatophagoides pteronyssinus), grass pollen mix, tree pollen mix, birch pollen, nettle pollen, Cladosporium herbarum, Alternaria alternata, cat fur, dog hair and a saline control (Bencard, Brentford, Middlesex, UK). The skin test responses were read after 15 minutes and measured as the mean of two right angled diameters, one of which was the largest. Tests were regarded as positive if the mean diameter of the weal was $3 \mathrm{~mm}$ or more, corrected for the mean diameter of the negative control weal if necessary. Individuals were regarded as being atopic if they had one or more positive skin prick tests.
METHACHOLINE CHALLENGE TEST

Where relevant, subjects were asked to refrain from smoking for at least two hours beforehand. Those who had had any symptoms of a viral illness during the preceding six weeks were excluded. The $\mathrm{FEV}_{1}$ was measured as the best of three blows using a Vitalograph spirometer. Methacholine challenge testing was not carried out on any subject who had an $\mathrm{FEV}_{1}$ of $<70 \%$ of that predicted or less than 1.51. Methacholine challenge was performed according to the method of Yan et al. ${ }^{11}$ Saline, followed by successive doubling doses of methacholine from $0.016 \mu \mathrm{mol}$ to $16.4 \mu \mathrm{mol}$, was administered. The test was stopped when $\mathrm{FEV}_{1}$ had fallen by $20 \%$ or more from the saline control or the highest concentration had been administered. The methacholine dose provoking a $20 \%$ fall in $\mathrm{FEV}_{1}\left(\mathrm{PD}_{20}\right)$ was calculated by interpolation. If a fall of $20 \%$ or more was not attained, $\mathrm{PD}_{20}$ was recorded as $>16.4 \mu \mathrm{mol}$

\section{STATISTICAL ANALYSIS}

Statistical analysis was carried out using the SPSS for Windows v. 6.0 program. Those who reported seasonal symptoms were compared with those who had no symptoms and reactors, defined as those who had a $\mathrm{PD}_{20}$ of $12.25 \mu \mathrm{mol}$ or less, were compared with non-reactors. For the analysis of the dietary information the method of Willet ${ }^{12}$ was employed. Residuals were calculated for the log transformed nutrients regressed on energy intake and tertiles for each nutrient determined. Logistic regression analyses were carried out to estimate the effects of low nutrient intakes on having symptoms or being a reactor. Adjusted analyses were carried out to control for the potential confounding effects of sex, age, and smoking habits (smokers versus non-smokers). The two sample $t$ test was used to compare age, $\mathrm{FEV}_{1}$, the log transformed $\mathrm{PD}_{20}$, and energy intake. The $\chi^{2}$ test was used to compare categorical data (smoking habits, atopy, and sex).

\section{Results}

Ninety individuals (60 women) agreed to participate in the study after explanation of the details over the telephone. Methacholine challenge was successfully carried out on 88 of them. It was not possible to obtain reliable information on the usage of food supplements from two individuals and they were omitted from subsequent dietary analysis. Subjects were initially allocated to one of two groups, with and without seasonal symptoms. Both groups were similar with respect to age, sex, smoking habits, and $\mathrm{FEV}_{1}$. As expected, a significantly higher proportion of cases, though not all, were atopic (relative risk 58, 95\% confidence interval (CI) 12.2 to 279.5) and $\mathrm{PD}_{20}$ was higher in controls (table 1), though the difference was not significant.

Antioxidant and energy intakes of cases and controls are shown in table 2. Total energy intake was slightly higher in controls, though not significantly so $(p=0.132)$. Controls had slightly higher intakes of all antioxidants which 
Table 3 Odds ratios for symptoms versus no symptoms in relation to antioxidant intake

\begin{tabular}{|c|c|c|c|c|c|c|}
\hline & \multicolumn{3}{|c|}{ Unadjusted odds } & \multicolumn{3}{|c|}{ Adjusted odds* } \\
\hline & Odds ratio & $95 \% C I$ & $p$ value & Odds ratio & $95 \% C I$ & $p$ value \\
\hline \multicolumn{7}{|l|}{ Retinol } \\
\hline Low & 0.62 & 0.22 to 1.73 & 0.359 & 0.64 & 0.23 to 1.80 & 0.397 \\
\hline Middle & 1.41 & 0.49 to 4.07 & 0.524 & 1.53 & 0.52 to 4.53 & 0.444 \\
\hline \multicolumn{7}{|l|}{$\beta$-carotene } \\
\hline Low & 1.11 & 0.61 to 2.02 & 0.728 & 0.92 & 0.31 to 2.71 & 0.881 \\
\hline Middle & 0.74 & 0.41 to 1.34 & 0.321 & 0.67 & 0.23 to 1.94 & 0.458 \\
\hline \multicolumn{7}{|l|}{ Vitamin C } \\
\hline Low & 0.92 & 0.32 to 2.61 & 0.871 & 0.95 & 0.32 to 2.77 & 0.918 \\
\hline Middle & 0.61 & 0.22 to 1.72 & 0.352 & 0.59 & 0.21 to 1.71 & 0.333 \\
\hline \multicolumn{7}{|l|}{ Vitamin E } \\
\hline Low & 1.41 & 0.49 to 4.07 & 0.524 & 1.50 & 0.51 to 4.41 & 0.467 \\
\hline Middle & 0.62 & 0.22 to 1.73 & 0.359 & 0.61 & 0.21 to 1.73 & 0.351 \\
\hline \multicolumn{7}{|c|}{ Magnesium } \\
\hline Low & 1.61 & 0.58 to 4.50 & 0.364 & 1.68 & 0.57 to 4.94 & 0.346 \\
\hline Middle & 2.87 & 0.98 to 8.37 & 0.053 & 2.95 & 0.98 to 8.86 & 0.054 \\
\hline \multicolumn{7}{|l|}{ Zinc } \\
\hline Low & 3.52 & 1.15 to 10.75 & 0.027 & 4.70 & 1.33 to 16.53 & 0.016 \\
\hline Middle & 0.94 & 0.33 to 2.61 & 0.902 & 1.03 & 0.36 to 2.94 & 0.958 \\
\hline \multicolumn{7}{|l|}{ Manganese } \\
\hline Low & 1.22 & 0.44 to 3.40 & 0.703 & 1.18 & 0.42 to 3.35 & 0.758 \\
\hline & 1.61 & 0.57 to 4.56 & 0.368 & 1.54 & 0.53 to 4.49 & 0.432 \\
\hline \multicolumn{7}{|l|}{ Selenium } \\
\hline Low & 1.62 & 0.57 to 4.66 & 0.367 & 1.64 & 0.56 to 4.84 & 0.367 \\
\hline Middle & 0.81 & 0.29 to 2.26 & 0.691 & 0.81 & 0.29 to 2.28 & 0.687 \\
\hline
\end{tabular}

* Adjusted for sex, age and smoking.

Table 4 Characteristics of methacholine reactors and non-reactors

\begin{tabular}{lccc}
\hline & $\begin{array}{c}\text { Reactors } \\
(n=29)\end{array}$ & $\begin{array}{c}\text { Non-reactors } \\
(n=58)\end{array}$ & $p$ value \\
\hline M:F & $6: 23$ & $24: 34$ & 0.056 \\
Mean (SD) age (years) & $36.7(9.70)$ & $37.5(11.44)$ & 0.766 \\
Smoking habits: & 9 & & \\
$\quad$ Current smokers & 5 & 13 & 0.683 \\
$\quad$ Ex-smokers & 15 & 34 & 0.223 \\
$\quad$ Never smokers & 16 & 24 & 0.077 \\
Mean (SD) FEV (\% predicted) & $110.2(14.90)$ & $116.1(14.44)$ & 0.934 \\
Mean (SD) FVC (\% predicted) & $111.1(14.28)$ & $111.6(14.67)$ & 0.009 \\
Previously diagnosed: & 6 & 2 & 0.170 \\
$\quad$ Asthma & 16 & 23 & 0.235 \\
Hay fever & 5 & 5 & 0.117 \\
$\quad$ Eczema & 8 & 8 & \\
Allergy & & & \\
\hline
\end{tabular}

$\mathrm{FEV}_{1}=$ forced expiratory volume in one second; $\mathrm{FVC}=$ forced vital capacity.

Table 5 Daily antioxidant and total energy intake for reactors and non-reactors

\begin{tabular}{lccccc}
\hline & \multicolumn{2}{l}{ Reactors } & & & Non-reactors \\
\cline { 2 - 3 } \cline { 5 - 6 } & $\begin{array}{l}\text { Geometric } \\
\text { mean }\end{array}$ & $\begin{array}{l}\text { Confidence } \\
\text { interval }\end{array}$ & & $\begin{array}{l}\text { Geometric } \\
\text { mean }\end{array}$ & $\begin{array}{l}\text { Confidence } \\
\text { interval }\end{array}$ \\
\hline Retinol $(\mu \mathrm{g})$ & 772 & 615 to 969 & & 759 & 636 to 906 \\
$\beta$-carotene $(\mu \mathrm{g})$ & 1673 & 1291 to 2169 & & 1099 & 1963 to 2486 \\
Vitamin C $(\mathrm{mg})$ & 77.3 & 62.8 to 95.2 & & 115.0 & 100.0 to 132.4 \\
Vitamin E (mg) & 6.65 & 5.56 to 7.96 & & 7.75 & 6.85 to 8.78 \\
Magnesium (mg) & 286 & 252 to 323 & & 322 & 298 to 348 \\
Zinc $(\mathrm{mg})$ & 9.68 & 8.77 to 10.69 & & 10.10 & 9.23 to 11.05 \\
Manganese $(\mathrm{mg})$ & 2.75 & 2.26 to 3.34 & & 3.30 & 2.95 to 3.68 \\
Selenium $(\mu \mathrm{g})$ & 64 & 53 to 77 & & 68 & 61 to 76 \\
Energy intake (kcal) & 1979 & 1729 to 2265 & & 2067 & 1879 to 2252 \\
\hline
\end{tabular}

Table 6 Odds ratios for reactors versus non-reactors in relation to antioxidant intake

\begin{tabular}{|c|c|c|c|c|c|c|}
\hline & \multicolumn{3}{|c|}{ Unadjusted odds } & \multicolumn{3}{|c|}{ Adjusted odds* } \\
\hline & Odds ratio & $95 \% C I$ & $p$ value & Odds ratio & $95 \% C I$ & $p$ value \\
\hline \multicolumn{7}{|l|}{ Retinol } \\
\hline Low & 1.12 & 0.36 to 3.51 & 0.839 & 1.13 & 0.35 to 3.64 & 0.840 \\
\hline Middle & 1.67 & 0.56 to 5.00 & 0.362 & 2.00 & 0.63 to 6.33 & 0.240 \\
\hline \multicolumn{7}{|l|}{$\beta$-carotene } \\
\hline Low & 2.59 & 0.81 to 8.31 & 0.110 & 3.43 & 0.97 to 12.11 & 0.056 \\
\hline Middle & 2.12 & 0.66 to 6.83 & 0.207 & 2.37 & 0.70 to 8.03 & 0.166 \\
\hline \multicolumn{7}{|l|}{ Vitamin C } \\
\hline Low & 5.66 & 1.68 to 19.04 & 0.005 & 7.13 & 1.91 to 26.71 & 0.004 \\
\hline Middle & 1.67 & 0.47 to 5.90 & 0.424 & 1.62 & 0.44 to 5.98 & 0.467 \\
\hline \multicolumn{7}{|l|}{ Vitamin E } \\
\hline Low & 1.53 & 0.50 to 4.64 & 0.455 & 1.89 & 0.59 to 6.11 & 0.284 \\
\hline Middle & 1.25 & 0.41 to 3.82 & 0.696 & 1.40 & 0.44 to 4.41 & 0.569 \\
\hline \multicolumn{7}{|l|}{ Magnesium } \\
\hline Low & 5.07 & 1.40 to 18.33 & 0.013 & 5.63 & 1.42 to 22.33 & 0.014 \\
\hline Middle & 4.41 & 1.22 to 15.99 & 0.024 & 4.03 & 1.07 to 15.20 & 0.039 \\
\hline \multicolumn{7}{|l|}{ Zinc } \\
\hline Low & 1.32 & 0.43 to 4.04 & 0.632 & 1.90 & 0.53 to 6.82 & 0.323 \\
\hline Middle & 1.45 & 0.48 to 4.38 & 0.512 & 1.76 & 0.55 to 5.62 & 0.337 \\
\hline \multicolumn{7}{|l|}{ Manganese } \\
\hline Low & 5.91 & 1.76 to 19.81 & 0.004 & 8.14 & 2.11 to 31.39 & 0.002 \\
\hline Middle & 1.82 & 0.52 to 6.46 & 0.348 & 1.59 & 0.43 to 5.89 & 0.485 \\
\hline \multicolumn{7}{|l|}{ Selenium } \\
\hline Low & 1.29 & 0.44 to 3.80 & 0.648 & 1.61 & 0.51 to 5.08 & 0.412 \\
\hline Middle & 1.05 & 0.34 to 3.22 & 0.928 & 1.18 & 0.37 to 3.75 & 0.780 \\
\hline
\end{tabular}

* Adjusted for sex, age and smoking. may be a reflection of their higher energy intakes. The unadjusted and adjusted odds ratios and associated $95 \%$ confidence intervals are presented in table 3 . For each antioxidant the odds ratios are given relative to the highest tertile. Adjusting for age, sex, and smoking habits made little difference to the odds ratios. The only significant result was for zinc, with those individuals in the lowest tertile of intake being observed to have an adjusted odds ratio 4.7 times those in the highest tertile.

Characteristics of methacholine reactors and non-reactors are given in table 4 . The two groups did not differ significantly with respect to age, smoking habits, $\mathrm{FEV}_{1}$, and atopy. The proportion of female reactors was somewhat higher, with the relative risk of a woman being a reactor of 2.71 (95\% CI 0.96 to 7.6$)$.

Antioxidant and energy intakes of reactors and non-reactors are shown in table 5 . With the exception of retinol and $\beta$-carotene, nonreactors had higher intakes of antioxidants. Again non-reactors had a higher energy intake, though this was not significant $(p=0.570)$. The difference in vitamin $\mathrm{C}$ intakes is particularly striking and it is unlikely that this is solely due to differences in energy intake. The unadjusted and adjusted odds ratios and associated 95\% CI are presented in table 6 . Odds ratios are again given relative to the highest tertile. In general, lower levels of antioxidant intake have associated odds ratios which are greater than one. After adjustment for age, sex and smoking habits, the lowest intakes of vitamin $\mathrm{C}$, magnesium, and manganese were significant. These differences in antioxidants were reflected in intakes of macronutrients (table 7). Reactors consumed more fats and less carbohydrates, fibre, and alcohol than non-reactors. The unadjusted and adjusted odds ratios along with $95 \%$ CI are presented in table 8 . Odds ratios are again given relative to the highest tertile. Adjusting for sex, age, and smoking habit did not alter the results to any significant extent. In general, lower intakes of any kind of fats were associated with a decreased risk of being a reactor. This decreased risk was significant for low intakes of fat, saturated fatty acids, and monounsaturated fatty acids. Lower tertiles of carbohydrates, fibre, and alcohol were associated with an increased risk of being a reactor. Both lower tertiles of carbohydrate intake were associated with a significantly increased risk of being a reactor. Those with the lowest intakes of fibre also had significantly increased risks of being a reactor.

It is recognised that, when a large number of independent tests are carried out, some of the tests may be expected to be statistically significant by chance. However, the very small $\mathrm{p}$ values for vitamin $\mathrm{C}(\mathrm{p}=0.004)$ and manganese $(p=0.002)$ suggest that, in these cases, the differences are unlikely to be due to chance.

\section{Discussion}

The objectives of this study were to test the hypothesis that differences in antioxidant intake are a factor in determining whether or not people develop seasonal symptoms and to in- 
Table 7 Daily macronutrient intake for reactors and non-reactors

\begin{tabular}{|c|c|c|c|c|}
\hline & \multicolumn{2}{|c|}{ Reactors $(n=29)$} & \multicolumn{2}{|c|}{ Non-reactors $(n=58)$} \\
\hline & $\begin{array}{l}\text { Geometric } \\
\text { mean }\end{array}$ & $\begin{array}{l}\text { Confidence } \\
\text { interval }\end{array}$ & $\begin{array}{l}\text { Geometric } \\
\text { mean }\end{array}$ & $\begin{array}{l}\text { Confidence } \\
\text { interval }\end{array}$ \\
\hline Protein $(\mathrm{g})$ & 80.4 & 72.9 to 88.8 & 82.0 & 75.2 to 89.4 \\
\hline Fat $(\mathrm{g})$ & 83.8 & 72.1 to 97.3 & 76.0 & 67.9 to 85.2 \\
\hline Saturated fatty acids (g) & 34.5 & 29.9 to 39.9 & 30.3 & 26.9 to 34.2 \\
\hline Monounsaturated fatty acids (g) & 31.3 & 27.0 to 36.2 & 29.2 & 26.4 to 32.3 \\
\hline Polyunsaturated fatty acids $(\mathrm{g})^{\prime}$ & 12.5 & 10.0 to 15.6 & 12.5 & 11.1 to 14.0 \\
\hline Cholesterol (mg) & 339.3 & 297.4 to 387.0 & 309.7 & 279.3 to 343.5 \\
\hline Carbohydrates (g) & 220.2 & 188.5 to 257.3 & 254.4 & 232.9 to 278.1 \\
\hline Starch $(\mathrm{g})$ & 117.5 & 99.8 to 138.3 & 123.8 & 111.3 to 137.8 \\
\hline Fibre $(\mathrm{g})$ & 12.4 & 10.4 to 14.9 & 15.9 & 14.6 to 17.4 \\
\hline Alcohol $(\mathrm{g})^{2}$ & 4.5 & 2.5 to 7.7 & 7.3 & 5.4 to 9.8 \\
\hline
\end{tabular}

No. of reactors $=28$, no. of non-reactors $=50$.

Weekly intake.

Table 8 Odds ratios for reactors versus non-reactors in relation to macronutrient intake

\begin{tabular}{|c|c|c|c|c|c|c|}
\hline & \multicolumn{3}{|c|}{ Unadjusted odds } & \multicolumn{3}{|c|}{ Adjusted odds* } \\
\hline & Odds ratio & $95 \% C I$ & $p$ value & Odds ratio & $95 \% C I$ & $p$ value \\
\hline \multicolumn{7}{|l|}{ Protein $(\mathrm{g})$} \\
\hline Low & 1.29 & 0.43 to 3.84 & 0.647 & 1.81 & 0.54 to 6.02 & 0.336 \\
\hline Middle & 0.90 & 0.30 to 2.75 & 0.860 & 1.01 & 0.31 to 3.27 & 0.982 \\
\hline \multicolumn{7}{|l|}{ Fat $(\mathrm{g})$} \\
\hline Low & 0.23 & 0.07 to 0.78 & 0.018 & 0.25 & 0.07 to 0.87 & 0.029 \\
\hline \multirow{2}{*}{\multicolumn{7}{|c|}{$\begin{array}{l}\text { Saturated fatty } \\
\text { acids (g) }\end{array}$}} \\
\hline & & & & & & \\
\hline Low & 0.10 & 0.03 to 0.42 & 0.002 & 0.11 & 0.03 to 0.44 & 0.002 \\
\hline Middle & 0.60 & 0.21 to 1.73 & 0.347 & 0.56 & 0.19 to 1.65 & 0.292 \\
\hline \multicolumn{7}{|c|}{$\begin{array}{l}\text { Monounsaturated } \\
\text { fatty acids (g) }\end{array}$} \\
\hline $\begin{array}{l}\text { fatty acids } \\
\text { Low }\end{array}$ & 0.25 & 0.08 to 0.80 & 0.019 & 0.28 & 0.09 to 0.92 & 0.036 \\
\hline Middle & 0.45 & 0.15 to 1.33 & 0.148 & 0.48 & 0.16 to 1.47 & 0.197 \\
\hline \multirow{2}{*}{\multicolumn{7}{|c|}{$\begin{array}{l}\text { Polyunsaturated } \\
\text { fatty acids }(\mathrm{g})^{1}\end{array}$}} \\
\hline & & & & & & \\
\hline Low & 0.46 & 0.15 to 1.43 & 0.177 & 0.52 & 0.15 to 1.77 & 0.296 \\
\hline Middle & 0.48 & 0.15 to 1.51 & 0.211 & 0.45 & 0.13 to 1.58 & 0.212 \\
\hline \multicolumn{7}{|c|}{ Carbohydrates (g) } \\
\hline Low & 6.25 & 1.72 to 22.67 & 0.005 & 10.52 & 2.41 to 45.89 & 0.002 \\
\hline Middle & 3.62 & 1.00 to 13.14 & 0.051 & 5.77 & 1.41 to 23.56 & 0.015 \\
\hline \multicolumn{7}{|c|}{ Cholesterol (mg) } \\
\hline Low & 0.44 & 0.15 to 1.32 & 0.144 & 0.50 & 0.16 to 1.59 & 0.238 \\
\hline Middle & 0.42 & 0.14 to 1.26 & 0.121 & 0.42 & 0.13 to 1.29 & 0.129 \\
\hline \multicolumn{7}{|l|}{ Starch $(\mathrm{g})$} \\
\hline Low & 0.89 & 0.29 to 2.77 & 0.839 & 0.93 & 0.28 to 3.07 & 0.906 \\
\hline Middle & 1.48 & 0.51 to 4.33 & 0.473 & 1.47 & 0.49 to 4.43 & 0.490 \\
\hline \multicolumn{7}{|l|}{ Fibre (g) } \\
\hline Low & 5.14 & 1.54 to 17.21 & 0.008 & 6.08 & 1.65 to 22.40 & 0.007 \\
\hline Middle & 2.16 & 0.62 to 7.49 & 0.225 & 2.24 & 0.61 to 8.29 & 0.226 \\
\hline \multicolumn{7}{|c|}{ Alcohol $(\mathrm{g})^{2}$} \\
\hline Low & 2.36 & 0.76 to 7.32 & 0.138 & 2.54 & 0.72 to 9.01 & 0.149 \\
\hline Middle & 1.57 & 0.50 to 4.91 & 0.437 & 2.00 & 0.59 to 6.77 & 0.266 \\
\hline
\end{tabular}

* Adjusted for sex, age, and smoking.

No. of reactors $=28$, no. of non-reactors $=50$

Weekly intake.
We have considered the possibility that the differences observed between reactors and nonreactors may have been due to a selection bias. All subjects were originally selected from a random population sample and there were no obvious differences between cases and controls in their reasons for inability to participate. It is possible that the controls were a particularly fit and health conscious group who might have had a better diet than the cases on that account. If that were the case, it is hard to explain why differences were not found between the original cases with symptoms and controls, rather than between the reactors and non-reactors. A general comparison of the diets of our subjects with those from another sample of a local population (which will necessarily include individuals with increased reactivity) suggests that both cases and controls in our study tended to eat less fat, fibre, retinol, and vitamin $\mathrm{E}$ and more vitamin $\mathrm{C}$ than people living in a nearby town.

On the other hand, there is already some evidence that our results reflect a real relationship between diet and asthma as our results are consistent with those of some earlier studies which concluded that individuals with bronchial hyperreactivity have reduced antioxidant intake or vice versa. Two studies have shown relatively low blood levels of selenium in subjects with asthma. ${ }^{1314}$ Selenium is essential to the activity of the glutathione peroxidase enzymes which are believed to be an important component of pulmonary antioxidant systems. Another study has shown that a low intake of magnesium, which is involved in the relaxation of smooth muscle, is associated with reduced lung function, bronchial hyperreactivity, and self-reported wheezing. ${ }^{15}$ Moreover, low intakes of fresh fruit and fruit juice have been shown to be associated with reduced lung function ${ }^{16}$ while a low vitamin $\mathrm{C}$ intake has been associated with reduction in $\mathrm{FEV}_{1} \cdot{ }^{1718}$ One study has shown that airways obstruction is associated with lower levels of serum retinol ${ }^{19}$ while another has suggested that various factors, including reduced serum levels of vitamin $\mathrm{C}$, were related to wheezing and bronchitis. ${ }^{20}$ The literature relating to vitamin $\mathrm{C}$ and asthma has recently been reviewed. ${ }^{21}$ Some studies have shown a beneficial effect and others none. Administration of vitamin $\mathrm{C}$ has been shown to attenuate bronchoconstriction induced by inhaling nitrogen dioxide $^{22}$ and ozone ${ }^{23}$ in normal subjects, and also to reduce bronchial reactivity to histamine and methacholine. ${ }^{2425}$

The accumulating evidence suggests that diet does have an influence in modulating the response of the lung to inhaled allergens and irritants. Clearly, genetic factors are influential in determining atopy, but genetic change is not the explanation for the remarkable rise in the prevalence of the three atopic diseases over the last 25 years. Substantial changes in the average household consumption of food have been documented in Britain over this period and these have included a marked fall in consumption of antioxidants and mineral cofactors in fresh fruit and vegetables, fresh fish, and 
meat. ${ }^{726}$ We have proposed that this change, operating over the whole population, has produced a general reduction in the ability of the lung to counter inflammatory reactions due to inhalation of irritants or allergens.

In the case of the newborn child, a low antioxidant level may make it more susceptible to the initial exposure to mite antigen that it encounters when arriving home, and later to exposure to grass pollen. Later in life a diet low in antioxidants may increase the risk of an atopic individual developing symptoms in response to exposure to higher doses of allergen. Our study, taken with the others quoted, suggests that diet may have such an influence throughout adult life. If it does, its importance is likely to be greater from an epidemiological point of view - shifting the population curve of susceptibility - than from a clinical point of view.

A dietary hypothesis would not explain all the epidemiological features of asthma and atopic disease. In particular, it does not explain why the first born child is more at risk than subsequent children, nor why members of large sibships are relatively protected, and it is possible that childhood infections may also play a part in modulating the expression of atopy. ${ }^{2728}$ It is, however, an attractive hypothesis in that, if true, it points the way to a means of reversing the progressive upward trend in atopic disease. Studies of the influence of dietary factors in pregnancy and early childhood on the expression of atopic disease are desirable.

1 Ninan TK, Russell G. Respiratory symptoms and atopy in Aberdeen schoolchildren: evidence from two surveys 25 years apart. BMf 1992;304:873-5.

2 Burr ML, Butland BK, King S, Vaughan Williams E. Changes in asthma prevalence: two surveys 15 years apart. Arch Dis Child 1989;64:1452-6.

3 Mitchell EA. Increasing prevalence of asthma in children. NZ Med F 1983;96:463-4.

4 Robertson CF, Heycock E, Bishop J, Nolan T, Olinsky A, Phelan PD. Prevalence of asthma in Melbourne schoolchildren: changes over 26 years. BMF 1991;302:1116-8.

5 Haahtela T, Lindholm H, Bjorksten F, Koskenvuo K, Laitinen LA. Prevalence of asthma in Finnish young men. BMF 1990;301:266-8.

6 Peat JK, Haby M, Spijker J, Berry G, Woolcock AJ. Prevalence of asthma in adults in Busselton, Western Australia. BMf 1992;305:1326-9.
7 Seaton A, Godden DJ, Brown K. Increase in asthma: a more toxic environment or a more susceptible population? Thorax 1994;49:171-4.

8 Soutar A, Harker C, Seaton A, Brooke M, Marr I. Oilseed rape and seasonal symptoms: epidemiological and environmental studies. Thorax 1994;49:352-6.

9 Bolton-Smith C, Smith WCS, Woodward M, TunstallPedoe H. Nutrient intakes of different social class groups: results from the Scottish Heart Health Survey (SHHS) Br F Nutr 1991;65:321-35.

10 Duthie GG, Shortt CT, Robertson JD, Walker KA, Arthur JR. Plasma antioxidants, indices of lipid peroxidation and coronary heart disease: risk factors in a Scottish population. Nutr Res 1992;12:S61-7.

11 Yan K, Salome C, Woolcock AJ. Rapid method for measurement of bronchial responsiveness. Thorax 1983;38:55-61.

12 Willet W. Implications of total energy intake for epidemiologic analyses. In: Willet W, ed. Nutritional epidemiology. Oxford: Oxford University Press, 1990;11. 245-71.

13 Stone J, Hinks LJ, Beasley R, Holgate ST, Clayton BA Reduced selenium status of patients with asthma. Clin $S$ 1989;77:495-500

14 Flatt A, Pearce N, Thomson CD, Sears MR, Robinson MF, Beasley R. Reduced selenium in asthmatic subjects in New Zealand. Thorax 1990;45:95-9.

15 Britton J, Pavord I, Richards K, Wisniewski A, Knox A, Lewis S, et al. Dietary magnesium, lung function, wheezing, and airway hyper-reactivity in a random adult population sample. Lancet 1994;344:357-62

16 Strachan DP, Cox, BD, Erzinclioglu W, Walters DE, Whichelow MJ. Ventilatory function and winter fresh fruit consumption in a random sample of British adults. Thorax 1991;46:624-9.

17 Schwartz J, Weiss ST. Relationship between dietary vitamin $\mathrm{C}$ intake and pulmonary function: the first National Health intake and pulmonary function: the first National Health Clin Nutr 1994;59:110-4.

18 Britton J, Pavord I, Richards K, Knox A, Wahedna I, Wisniewski A, et al. The effects of dietary antioxidants on Wisniewski A, et al. The effects of dietary antioxidants on lung function in the

19 Morabia A, Menkes MJS, Comstock GW, Tockman MS Serum retinol and airway obstruction. Am $\mathcal{F}$ Epidemiol

20 Schwartz J, Weiss ST. Dietary factors and their relation to respiratory symptoms: the second national health and nutrition examination survey. Am f Epidemiol 1990;132. $67-76$

21 Bielory L, Gandhi R. Asthma and vitamin C. Ann Allergy 1994;73:89-96

22 Mohsenin V. Effect of vitamin $\mathrm{C}$ on $\mathrm{NO}_{2}$-induced airwa hyperresponsiveness in normal subjects. A randomized double-blind experiment. Am Rev Respir Dis 1987;136 1408-11.

23 Chatham MD, Eppler JH, Sauder LR, Green D, Kulle TJ Evaluation of the effects of vitamin $\mathrm{C}$ on ozone-induced bronchoconstriction in normal subjects. Ann NY Acad Sci 1987;498:269-79

24 Zuskin E, Lewis AJ, Bouhuys A. Inhibition of histamine induced airway constriction by ascorbic acid. $\mathcal{F}$ Allergy Clin Immunol 1975;51:218-26.

25 Mohsenin V, DuBois AB, Douglas JS. Effect of ascorbic acid on response to methacholine in asthmatic subjects. Am Rev Respir Dis 1983;127:143-7.

26 Ministry of Agriculture Fisheries and Food. Household food consumption and expenditure. Annual reports of the National Food Survey Committee. London: HMSO, 1961-90.

27 Von Mutius E, Martinez FD, Fritzsch C, Nicolai T, Reitmeir $\mathrm{P}$, Thiemann H-H. Skin test reactivity and number of siblings. BMF 1994;308:692-5.

28 Shaheen SO, Aaby P, Hall AJ, Barker DJP, Heyes CB, Shiell AW, et al. Measles and atopy in Guinea-Bissau. Lancet 1996;347:1792-6. 